\title{
PEMBERDAYAAN EKONOMI KELUARGA MELALUI USAHA PENINGKATAN PENDAPATAN KELUARGA SEJAHTERA (UPPKS) (Studi Kasus di Desa Sukorejo Kecamatan Saradan Kabupaten Madiun)
}

\author{
Sudarmiani $^{1)}$, Waini Astuti ${ }^{2)}$ \\ Universitas PGRI Madiun \\ aniwidjiati@unipma.ac.id ${ }^{1)}$,whayniee@gmail.com ${ }^{2)}$
}

\begin{abstract}
This study aims to determine the implementation of the UPPKS program, the role of UPPKS cadres, the supporting components of the UPPKS program and obstacles in family economic empowerment activities through the UPPKS program in Sukorejo Village, Saradan, Madiun. The type of research used is descriptive qualitative with a case study approach. Data sources used are primary data and secondary data. Data collection is done by observation, interviews and documentation. The validity of the data uses source triangulation. The results show, (1) The implementation of family economic empowerment through the UPPKS program in Sukorejo Village runs quite well in savings and loan activities. (2) The role of UPPKS cadres in Sukorejo Village is as facilitators in conveying what their members want to the UPPKS program organizers. (3) Supporting components in the implementation of UPPKS activities in Sukorejo Village are Village Village, Saradan $P L K B$, and BKKBN. (4) Obstacles in the process of family economic empowerment through the UPPKS program in Sukorejo Village, namely the existence of members who are less active in the activities of UPPKS groups and members who move domiciles, so that UPPKS members are reduced.
\end{abstract}

Keywords : Family Economic Empowerment, UPPKS Programs.

\begin{abstract}
Abstrak
Penelitian ini bertujuan untuk mengetahui pelaksanaan, peran kader, komponen pendukung dan hambatan dalam kegiatan pemberdayaan ekonomi keluarga melalui program UPPKS (Usaha Peningkatan Pendapatan Keluarga Sejahtera) di Desa Sukorejo Kecamatan Saradan Kabupaten Madiun. Jenis penelitian yang digunakan adalah deskriptif kualitatif dengan pendekatan studi kasus. Sumber data yang digunakan yaitu data primer dan data sekunder. Pengumpulan data dilakukan dengan cara observasi, wawancara dan dokumentasi. Keabsahan data menggunakan triangulasi sumber. Hasil menunjukkan, (1) Pelaksanaan pemberdayaan ekonomi keluarga melalui program UPPKS di Desa Sukorejo ini berjalan cukup baik dalam kegiatan simpan pinjam. (2) Peran para kader UPPKS di Desa Sukorejo yaitu sebagai fasilitator dalam menyampaikan apa yang diinginkan oleh anggotanya kepada pihak penyelenggara program UPPKS. (3) Komponenkomponen pendukung dalam pelaksanaan kegiatan UPPKS di Desa Sukorejo adalah Kelurahan Desa, PLKB (Penyuluh Lapangan Keluarga Berencana) Kecamatan Saradan, dan BKKBN. (4) Hambatan atau kendala dalam proses pemberdayaan ekonomi keluarga melalui program UPPKS di Desa Sukorejo yakni adanya anggota yang kurang aktif dalam kegiatan kelompok UPPKS dan anggota yang pindah domisili, sehingga anggota UPPKS menjadi berkurang.
\end{abstract}

Kata Kunci: Pemberdayaan Ekonomi Keluarga, Program UPPKS. 


\section{PENDAHULUAN}

Kemiskinan seringkali dipahami sebagai gejala rendahnya tingkat kesejahteraan, secara ekonomi kemiskinan dapat diartikan sebagai kurangnya sumber daya yang dapat digunakan untuk meningkatkan kesejahteraan masyarakat. Kemiskinan ini dapat diukur secara langsung dengan menetapkan persediaan sumber daya yang tersedia pada suatu kelompok masyarakat. Upaya pemberdayaan masyarakat miskin agar dapat mandiri, baik dalam pengertian ekonomi, budaya dan politik merupakan hakekat utama dalam penanggulangan kemiskinan. Kemampuan masyarakat untuk mewujudkan dan mempengaruhi arah serta pelaksanaan suatu program ditentukan dengan mengendalikan kemampuan yang dimilikinya sehingga pemberdayaan (empowerment) merupakan jiwa partisipasi yang sifatnya aktif dan kreatif.

Pemberdayaan dalam hal menuntaskan kemiskinan dapat dilakukan dengan cara mengubah mind set individu dan masyarakat untuk berdaya dan mandiri. Pemberdayaan juga bisa dilakukan melalui berbagai aktivitas yang dapat meningkatkan partisipasi individu dan masyarakat. Bentuk aktivitas pemberdayaan tersebut yaitu kegiatan pendidikan dan latihan yang dapat mendorong kemampuan dan keterampilan yang sesuai dengan potensi dan kebutuhan masyarakat, kegiatan pendampingan yang dilakukan secara berkelanjutan, menumbuhkan lembagalembaga non formal dalam masyarakat, menciptakan berbagai kesempatan kerja, menghidupkan kembali budaya dan kearifan lokal sebagai modal sosial, dan bentuk aktivitas lainnya (Anwas, 2014).

Kegiatan pemberdayaan tersebut merupakan pembangunan sosial yang menjadi gerakan masyarakat yang didukung oleh semua unsur dari seluruh kalangan mulai pemerintah, anggota legislatif, perguruan tinggi, dunia usaha, LSM, organisasi sosial, masyarakat, dan juga media masa. Kegiatan pemberdayaan ini dilakukan secara bertahap dan berkelanjutan yang menyentuh semua lapisan masyarakat.

Berbagai upaya pembangunan telah dilakukan pemerintah selama ini, terutama dalam memberikan peluang kepada masyarakat miskin untuk meningkatkan kesejahteraan. Salah satu bentuk upaya menanggulangi kemiskinan, Kantor Menteri Negara Kependudukan BKKBN mendirikan program UPPKS yaitu usaha peningkatan pendapatan keluarga sejahtera dengan tujuan meningkatkan pendapatan untuk pemenuhan kebutuhan rumah tangga.

Usaha Peningkatan Pendapatan Keluarga Sejahtera(UPPKS) adalah kelompok usaha ekonomi produktif yang beranggotakan sekumpulan anggota keluarga yang saling berinteraksi dan terdiri dari berbagai tahapan KS (Keluarga Sejahtera), baik PUS (Pasangan Usia Subur) yang sudah ber-KB maupun yang belum ber-KB serta masyarakat umum dalam rangka meningkatkan tahapan kesejahteraan dan memantapkan kesertaan ber-KB (BKKBN, 2010).

Salah satu hal yang mendasarinya adalah bahwa tanpa kondisi yang baik, mustahil keluarga dapat meningkatkan kesejahteraanya. Hal ini harus dimulai dari memberdayakan keluarga dibidang ekonomi. Dengan demikian program UPPKS ini diharapkan dapat menjadi model usaha mikro keluarga yang berfungsi untuk menggerakkan roda ekonomi keluarga melalui kegiatan ekonomi dengan cara menggugah minat dan semangat keluarga untuk berwirausaha.

BKKBN (2009) menyebutkan "Program Pemberdayaan Ekonomi Keluarga sebagai program beyond family planning bertujuan untuk meningkatkan kesejahteraan keluarga, khususnya peserta KB Keluarga Pra Sejahtera dan Keluarga Sejatera I (KS I)". Sedangkan BKKBN (2015) menyebutkan "Pemberdayaan ekonomi keluarga adalah 
upaya yang dilakukan oleh pemerintah melalui kantor pengelola KB untuk membantu keluarga agar memiliki kegiatan ekonomi produktif yang diharapkan akan dapat meningkatkan ekonomi keluarga".

Program UPPKS pada prinsipnya adalah kelompok ekonomi usaha produktif yang beranggotakan ibu-ibu atau wanita antara lain berasal dari keluarga PraSejahtera, Sejahtera I, Sejahtera II, Sejahtera III dan Sejahtera IV baik yang belum, sedang maupun purna peserta KB guna meningkatkan pendapatan keluarga dalam rangka mewujudkan keluarga kecil bahagia sejahtera. Secara khusus program kelompok UPPKS ditujukan kepada pemberdayaan ibu rumah tangga, melalui program ini ibu rumah tangga dapat melakukan kegiatan usaha ekonomi produktif dengan kemudahan akses pada modal sehingga dapat membantu kelancaran dalam kegiatan usaha tersebut.

Kelompok UPPKS difokuskan kepada para ibu atau wanita dengan pertimbangan bahwa kaum ibu adalah anggota keluarga yang memiliki banyak perandalam mengembangkan dan melaksanakan fungsi keluargadan potensi kaum ibu dalam bidang ekonomiini yang belum dimanfaatkan secara optimal. Beberapa kajian tentang UPPKS menunjukkan bahwa salah satu faktor sentral yang mempengarui keberhasilan program kelompok UPPKS adalah figur pengurus, modal, jenis usaha, pembinaan, pengalaman dan kemampuan dalam pengelola sumber daya keluarga.

Pemberdayaan ekonomi keluarga merupakan suatu proses atau kegiatan agar sebuah keluarga mampu melakukan kegiatan ekonomi untuk kesejahteraan keluarganya. Salah satu desa yang melaksanakan program UPPKS ini adalah Desa Sukorejo Kecamatan Saradan Kabupaten Madiun. UPPKS di Desa Sukorejo ini bergerak dalam kegiatan simpan pinjam, dengan memberikan pinjaman modal pada anggota yang ingin mendirikan usaha mikro agar dapat membantu kegiatan ekonomi dan mensejahterakan keluarga di Desa Sukorejo tersebut.

Suwondo (2017), menunjukkan bahwa model pemberdayaan masyarakat Kelurahan Langensari Kecamatan Ungaran Barat Kabupaten Semarang dilakukan melalui 1) proses pemberdayaan masyarakat menggunakan pendekatan partisipasi aktif, 2) strategi pemberdayaan masyarakat menerapkan pendekatan dan pendampingan kelompok, dan 3) faktor pendukung semua komponen dari Kabupaten sampai dengan kelurahan sangat mendukung dengan adanya kelompok UPPKS.

Intan Riana Dewi (2016), Program Usaha Peningkatan Pendapatan Keluarga Sejahtera (UPPKS) Terhadap Kelompok SOKA di Gunungketur Pakualaman Yogyakarta dikatakan efektif ditandai masih adanya perputaran modal yang berjalan dengan lancar.

Untuk menghindari luasnya permasalahan dalam penelitian ini, maka masalah penelitian difokuskan tentang: 1. Bagaimana pelaksanaan kegiatan pemberdayaan ekonomi keluarga melalui program UPPKS di Desa Sukorejo Kecamatan Saradan Kabupaten Madiun?; 2. Bagaimana peran para kader UPPKS di Desa Sukorejo Kecamatan Saradan Kabupaten Madiun?; 3. Apa komponen-komponen pendukung pelaksanaan kegiatan UPPKS di Desa Sukorejo Kecamatan Saradan Kabupaten Madiun?; 4. Apa hambatan-hambatan dalam proses pemberdayaan ekonomi keluarga melelui program UPPKS di Desa Sukorejo Kecamatan Saradan Kabupaten Madiun?

Dalam pelaksanaan pendekatan pemberdayaan berpijak pada pedoman dan prinsip pekerjaan social, terdapat beberapa prinsip pemberdayaan menurut prespektif pekerjaan sosial, yaitu: 1) Pemberdayaan adalah proses kolaborasi, karenanya pekerja sosial dan masyarakat harus bekerja sama 
sebagai partner; 2) Proses pemberdayaan menempatkan masyarakat sebagai subjek (actor) yang kompeten dan mampu menjangkau sumber-sumber dan kesempatankesempatan; 3)Masyarakat harus melihat diri mereka sendiri sebagai agen penting yang dapat mempengaruhi perubahan; 4) Kompetensi diperoleh melalui pengalaman hidup, khususnya pengalaman yang memberikan perasaan mampu pada masyarakat; 5)Solusi-solusi yang berasal dari situasi khusus, harus beragam dan menghargai keberagaman dan meningkatkan kompetensi serta kemampuan mengendalikan seseorang; 6) Masyarakat harus berpartisipasi dalam pemberdayaan mereka sendiri, tujuan, cara dan hasil harus dirumuskan oleh mereka sendiri; 7) Tingkat kesadaran merupakan kunci dalam pemberdayaan, karena pengetahuan dapat memobilisasi tindakan bagi perubahan; 8) Pemberdayaan melibatkan akses terhadap sumber-sumber dan kemampuan untuk menggunakannya secara efektif; 9) Proses pemberdayaan bersifat dinamis, strategis, berubah terus, evolutif dan permasalahan selalu memiliki beragam solusi; 11) Pemberdayaan dicapai melalui stuktur-struktur personal dan pembangunan ekonomi secara parallelSuharto (2014).

Sedangkan Persons (dalam Suharto, 2014), mengajukan tiga dimensi pemberdayaan yang merujuk pada: 1) Sebuah proses pembangunan yang bermula dari pertumbuhan individual yang kemudian berkembang menjadi sebuah perubahan sosial yang lebih besar; 2) Sebuah keadaan psikologis yang ditandai oleh rasa percaya diri, berguna dan mampu mengendalikan diri dan orang lain; 3) Pembebasan yang dihasilkan dari sebuah gerakan sosial, yang mulai dari pendidikan dan politisasi orang-orang lemah dan kemudian melibatkan upaya-upaya kolektif dari orang-orang lemah tersebut untuk memperoleh kekuasaan dan mengubah struktur-struktur yang masih menekan.
Untuk mengetahui fokus dan tujuan pemberdayaan secara operasional, maka perlu diketahui berbagai indikator pemberdayaan yang dapat menunjukkan seseorang itu berdaya atau tidak. Sehingga ketika sebuah program pemberdayaan diberikan, maka segenap upaya dapat dikonsentrasikan pada aspek-aspek apa saja dari sasaran perubahan yang perlu dioptimalkan.

Pemberdayaan merupakan implikasi dari strategi pembangunan yang berbasis pada masyarakat (people centered development). Terkait dengan hal ini, apapun pengertian yang diberikan terhadapnya, selalu merujuk pada upaya perbaikan, terutama perbaikan pada mutu hidup manusia, baik secara fisik, mental, ekonomi, maupun sosial budayanya.

Pembinaan diberikan kepada seluruh pengurus dan anggota kelompok UPPKS (Usaha Peningkatan Pendapatan Keluarga Sejahtera) untuk meningkatkan kemampuan anggota sesuai bidang usahanya, dan mendorong minat usaha anggota bagi kemajuan usaha kelompok. Dalam BKKBN Seri 2 (2009), menyebutkan bahwa pembinaan-pembinaan yang tedapat dalam kelompok UPPKS ini yaitu:

1) Pembinaan Organisasi

a) Mempunyai rasa memiliki terhadap kelompoknya.

b) Mengikuti kegiatan kelompok UPPKS secara aktif.

c) Mematuhi kesepakatan yang berlaku dalam kelompok.

2) Pembinaan Permodalan

a) Menggunakan modal pinjaman untuk kegiatan usaha.

b) Mematuhi aturan dalam proses pinjam meminjam.

c) Rajin berhemat dan menabung untuk memupuk modal dan mengembangkan usahanya.

3) Pembinaan Usaha Ekonomi Produktif

a) Rajin berusaha

b) Memilih jenis usaha yang sesuai 
dengan keterampilan atau kemampuannya dan sumber bahan baku yang ada.

c) Memilih jenis usaha dengan memperhatikan kebutuhan pembeli.

d) Selalu berusaha untuk meningkatkan mutu hasil usahanya.

4) Pembinaan Administrasi dan Pembukuan

Dalam pembinaan administrasi dan pembukuan, para anggota dibimbing dan diajarkan untuk dapat mengerjakan pembukuan kegiatan usahanya. Pembukuan tersebut nantinya akan membantu para anggota untuk mengetahui laba atau rugi dari usaha yang dijalankannya.

5) Pembinaan Pemasaran

Dalam pembinaan pemasaran ini, para anggota kelompok dibimbing agar rajin mencari, memanfaatkan dan bila memungkinkan menciptakan peluang pasar.

6) Pembinaan Kesertaan Ber-KB

a) Anggota kelompok UPPKS yang belum ber-KB dibina agar menjadi peserta $\mathrm{KB}$ dengan menggunakan salah satu jenis alat atau obat kontrasepsi apa saja.

b) Setelah menjadi peserta KB, anggota kelompok UPPKS dibimbing lebih lanjut agar beralih menggunakan alat kontrasepsi mantap dan menjadi peserta KB.

c) Secara bertahap, anggota juga dibimbing agar mau datang sendiri ke PPKBD atau Puskesmas dan tempat pelayanan KB lainnya.

\section{METODE PENELITIAN}

Penelitian ini dilakukan di Desa Sukorejo di Jalan Perguruan Ilmu Sejati No. 01 Kecamatan Saradan Kabupaten Madiun. Peneliti tertarik melakukan penelitian di tempat ini dengan alasan terdapat dikarenakan kesesuaian objek penelitian dengan tema yang di teliti. Jenis penelitian yang digunakan adalah penelitian kualitatif dengan pendekatan studi kasus. Metode penelitian kualitatif adalah metode penelitian yang digunakan untuk meneliti pada kondisi obyek yang alamiah, dimana peneliti adalah sebagai instrumen kunci, teknik pengumpulan data dilakukuan secara triangulasi (gabungan), analisis data bersifat induktif, dan hasil penelitian kualitatif lebih menekankan makna daripada generalisasi.

Sumber data dapat diperoleh dari data primer (langsung) dan data sekunder (tidak langsung). Sumber data primer yang digunakan dalam penelitian ini diperoleh dari teknik wawancara, kemudian akan diolah oleh peneliti, seperti: wawancara dengan petugas PLKB, ketua UPPKS, dan anggota UPPKS di Desa Sukorejo Kecamatan Saradan Kabupaten Madiun. Sumber data sekunder dalam penelitian ini diperoleh dari dokumen-dokumen, catatan-catatan, laporanlaporan, maupun arsip-arsip resmi UPPKS di Desa Sukorejo Kecamatan Saradan Kabupaten Madiun.

Teknik pengumpulan data dalam penelitian kualitatif ini bersifat deskriptif, sumber data primer adalah peneliti yang melakukan tindakan dan kelompok UPPKS yang menerima tindakan. Sedangkan data sekunder yaitu berupa data dari hasil wawancara, observasi, dokumentasi dan triangulasi.

Untuk mendapatkan data yang valid dan kredibel dalam penelitian diperlukan teknik keabsahan data. Dalam penelitian ini menggunakan teknik triangulasi. Menurut Sugiyono (2013) “dalam teknik pengumpulan data, triangulasi diartikan sebagai teknik pengumpulan data yang bersifat menggabungkan dari berbagai teknik pengumpulan data dan sumber data yang telah ada". Menurut Sugiyono (2013) ada 3 (tiga) macam triangulasi, yaitu:

1. Triangulasi sumber

Triangulasi sumber, berarti untuk menguji 
kredibilitas data dilakukan dengan cara mengecek data yang telah diperoleh melalui beberapa sumber.

2. Triangulasi teknik

Triangulasi teknik, berarti untuk menguji kredibilitas data dilakukan dengan cara mengecek data kepada sumber yang sama dengan teknik yang berbeda.

3. Triangulasi waktu

Triangulasi waktu, berarti data yang dikumpulkan dengan teknik wawancara di pagi hari pada saat narasumber masih segar, blum banyak masalah akan memberikan data yang lebih valid sehingga lebih kredibel.

Berdasarkan uraian di atas, peneliti menggunakan teknik triangulasi karena triangulasi dilakukan dengan sumber data dan peneliti atau pengamat lain. Teknik triangulasi yang digunakan dalam penelitian ini adalah teknik triangulasi sumber karena dalam penelitian ini untuk melakukan pengecekan data dilakukan dengan membandingkan dengan melakukan wawancara pada petugas PLKB, ketua UPPKS, dan anggota UPPKS di Desa Sukorejo Kecamatan Saradan Kabupaten Madiun.

\section{HASIL DAN PEMBAHASAN}

Hasil penelitian yang disajikan disini merupakan hasil penelitian yang diperoleh dari hasil observasi, wawancara dan dokumentasi. Adapun wawancara ini peneliti tujukan kepada koordinator PLKB, petugas PLKB, ketua UPPKS di Desa Sukorejo dan dua anggota UPPKS. Berikut pembahasan hasil penelitian yang telah peneliti peroleh.

Pelaksanaan kegiatan pemberdayaan ekonomi keluarga melalui program UPPKS di Desa Sukorejo Kecamatan Saradan Kabupaten Madiun.

Dalam melaksanakan pemberdayaan khususnya kepada masyarakat, agen pemberdayaan perlu memegang prinsip- prinsip pemberdayaan. Salah satu prinsip tersebut yaitu dalam kegiatan pemberdayaan harus didasarkan pada kebutuhan, masalah dan potensi masyarakat sasaran. Pada hakikatnya, manusia mempunyai kebutuhan dan potensi dalam dirinya untuk dapat dikembangkan dan diberdayakan untuk dapat mandiri (Anwas, 2014).

Dari hasil penelitian yang dilakukan peneliti terdapat kelompok UPPKS di Desa Sukorejo yang sedang aktif bergerak dalam kegiatan simpan pinjam. Dalam pelaksanaannya kelompok UPPKS di Desa Sukorejo ini sudah berjalan cukup baik. Dibuktikan dengan adanya beberapa pernyataan dari responden (informan) terkait, yaitu awal pembentukan kelompok ini adalah adanya program dari BKKBN, dengan adanya program tersebut dan tujuan yang sama antara ibu-ibu agar usahanya dapat berkembang maka dibentuk kelompok UPPKS di Desa Sukorejo ini dengan tujuan agar ibu-ibu dapat mengelola usahanya lebih baik lagi dan juga dapat mengetahui tata cara pelaporan keuangan dalam usahanya.

Selain itu, bentuk pendampingan dari PLKB terhadap kelompok UPPKS yang ada di Desa Sukorejo adalah dengan memberikan sosialisasi mengenai program UPPKS dan pelatihan-pelatihan bagi para ibu yang memiliki potensi (seperti membuat ketrampilan dari anyaman, memasak dan lain-lain) dan juga memberikan bantuan pinjaman dana untuk mendirikan usahanya dengan laporan keuangan yang sudah terprogram sesuai aturan yang ditentukan. Untuk tata cara pembukuan kelompok UPPKS Desa Sukorejo ini yaitu jenis-jenis buku dan pencatatan atau pembukuan yang harus disediakan oleh kelompok UPPKS dapat disesuaikan dengan kondisi dan kemampuan kelompok yang bersangkutan.

Kemudian adanya kader (pengurus) yang masih aktif dan anggota UPPKS yang masih melakukan simpan pinjam dalam 
kelompok. Syarat untuk menjadi pengurus ataupun anggota dalam kelompok UPPKS ini tidak sulit yaitu pengurus ataupun anggota harus domisili di tempat atau Desa kelompok UPPKS itu dibuat. Selain itu adanya pertemuan yang masih aktif setiap bulannya untuk membahas simpan pinjam, pemberian modal, pengelolaan usaha dan termasuk didalamnya membahas anggota mendapatkan keuntungan atau tidak dari usahanya tersebut serta membahas kendala apa saja yang dihadapi oleh anggotanya baik dalam menjalankan usaha maupun dalam keikutsertaannya pada kelompok UPPKS ini. Anggota yang tergabung dalam kelompok ini masing-masing memiliki usaha kecil sendiri, seperti warung dan sebagai penjahit.

Peran para kader (pengurus) UPPKS di Desa Sukorejo Kecamatan Saradan Kabupaten Madiun.

Pembentukan kepengurusan pada prinsipnya diserahkan penuh kepada musyawarah kelompok. Minimal kepengurusan UPPKS ini terdiri dari ketua UPPKS, sekretaris, dan bendahara (BKKBN, 2010).

Dari hasil penelitian diketahui kelompok UPPKS di Desa Sukorejo ini diketuai oleh Ibu Sugiyati dengan 6 (enam) orang anggota termasuk pengurus (kader) kelompok. Pengurus kelompok UPPKS di Desa Sukorejo ini terdiri dari ketua yaitu Ibu Sugiyati, sekretaris yaitu Ibu Titik dan bendahara yaitu Ibu Dwi serta ada 4 (empat) orang anggota yaitu Ekowati, Leni, Sunarni dan Suprihatin. Para kader dalam kelompok ini berperan sebagai:

a) Fasilitator dalam menyampaikan aspirasi dari anggotanya kepada pihak penyelenggara program UPPKS di Desa Sukorejo.

b) Mengatur dan mencatat keuangan (administrasi) serta mengurusi keperluan atau kebutuhan anggota UPPKS Desa Sukorejo.

c) Berusaha mewujudkan keinginan anggota demi kemajuan kelompok UPPKS di Desa Sukorejo. d) Mengurusi segala kegiatan kelompok UPPKS Desa Sukorejo (mengadakan jadwal pertemuan atau rapat bulanan).

Komponen-komponen pendukung pelaksanaan kegiatan UPPKS di Desa Sukorejo Kecamatan Saradan Kabupaten Madiun.

Dari hasil penelitian kelompok UPPKS di Desa Sukorejo ini didukung penuh oleh komponen-komponen yang ada yaitu:

a) Kelurahan Desa Sukorejo,

b) PLKB kecamatan Saradan, dan

c) $\mathrm{BKKBN}$

Ketiga komponen tersebut yang siap membantu dan menaungi kelompok UPPKS tersebut. Dengan dukungan penuh yang diberikan dari pihak tersebut kelompok UPPKS ini dapat menjalankan fungsinya untuk kegiatan maupun rapat anggota setiap bulannya dan membantu anggotanya dalam mengelola usaha yang dijalankan. Dari dukungan tersebut kelompok UPPKS ini akan dapat mewujudkan tujuannya dalam membantu mensejahterakan kehidupan masyarakat.

Hambatan dalam proses pemberdayaan ekonomi keluarga melalui program UPPKS di Desa Sukorejo Kecamatan Saradan Kabupaten Madiun.

Dari hasil penelitian bahwa hambatan yang ditemukan pada proses pemberdayaan ekonomi keluarga melalui program UPPKS di Desa Sukorejo ini yaitu:

a) Anggota yang macet karena pindah domisili atau tempat tinggal ke Desa lain sehingga anggota menjadi berkurang.

b) Kurangnya kesadaran dari anggota untuk mengikuti pertemuan (rapat) sehingga banyak anggota yang kurang aktif dalam kelompok, hal tersebut berdampak pada kurang pahamnya anggota mengenai prosedur dalam kegiatan simpan pinjam didalam kelompok UPPKS yang ada di Desa Sukorejo ini.

c) Kader yang kurang cekatan dalam menangani masalah pada anggotannya. 
d) Pelatihan dan sosialisasi yang kurang maksimal dalam kelompok UPPKS.

Dengan adanya kelompok UPPKS di Desa Sukorejo ini, banyak dirasakan manfaatnya terutama oleh anggota UPPKS. Manfaat yang dirasakan salah satunya dalam kelompok UPPKS ini anggota diberikan pinjaman modal untuk membuat usaha sendiri serta diberikan pengarahan mengenai mengelola sebuah usaha agar bisa berkembang dengan baik agar bisa mendapatkan keuntungan dari usaha yang dijalankan. Dengan adanya kelompok UPPKS ini dapat berdampak pada peningkatan pendapatan keluarga masing-masing anggota kelompok UPPKS yang ada di Desa Sukorejo ini.

Dari hasil penelitian dalam pelaksanaannya, kelompok UPPKS di Desa Sukorejo ini memiliki potensi agar masyarakat dapat berkembang secara optimal dengan adanya usaha ekonomi produktif yang dikelola oleh anggotanya. Selain itu penguatan dan perlindungan diberikan oleh para kader (pengurus) yang bisa menyampaikan aspirasi dari anggotanya kepada pihak penyelenggara program UPPKS. Sebagai penyokongan dan pemeliharaan dalam penelitian ini diketahui bahwa terdapat komponen-komponen pendukung yang siap membantu melancarkan kegiatan kelompok UPPKS yaitu Kelurahan Desa Sukorejo, Petugas PLKB (Penyuluh Lapangan Keluarga Berencana) Kecamatan Saradan dan BKKBN. Komponen-komponen tersebut siap menaungi kelompok-kelompok UPPKS dalam melaksanakan kegiatannya, termasuk kelompok UPPKS yang ada di Desa Sukorejo ini.

\section{PENUTUP}

\section{Simpulan}

Berdasarkan hasil penelitian dan pembahasan yang disampaikan, maka dapat disimpulkan sebagai berikut:

a. Pelaksanaan pemberdayaan ekonomi keluarga melalui program UPPKS di Desa
Sukorejo ini berjalan cukup baik dalam kegiatan simpan pinjam.

b. Peran para kader UPPKS di Desa Sukorejo yaitu sebagai fasilitator dalam menyampaikan aspirasi anggota kepada penyelenggara program, mengatur dan mencatat setiap administrasi (keuangan) anggota dan mengurus jadwal pertemuan (rapat anggota) pada kelompok UPPKS Desa Sukorejo.

c. Komponen-komponen pendukung dalam pelaksanaan kegiatan UPPKS di Desa Sukorejo adalah Kelurahan Desa Sukorejo, PLKB (Penyuluh Lapangan Keluarga Berencana) Kecamatan Saradan, dan BKKBN.

d. Hambatan dalam program UPPKS ini, yaitu adanya anggota yang kurang aktif dalam kegiatan kelompok UPPKS, kader yang kurang cekatan dalam menangani masalah yang ada pada anggotanya dan adanya anggota yang pindah domisili sehingga anggota UPPKS menjadi berkurang serta pelatihan dan sosialisasi yang kurang maksimal dalam kelompok UPPKS di Desa Sukorejo

\section{Saran}

Berdasarkan simpulan yang telah diuraikan diatas, saran yang dapat berikan yaitu:

a. Bagi UPPKS Desa Sukorejo

1) Lebih melakukan seleksi perekrutan menjadi anggota UPPKS sehingga yang menjadi anggota UPPKS benarbenar anggota yang sesuai dengan persyaratan yang telah ditetapkan pihak penyelenggara program agar dapat menjalankan kewajiban sebagai anggota dalam mengembangkan usaha ekonomi produktifnya.

2) Untuk setiap anggota UPPKS harus menyadari dan tidak lagi menyepelekan hal-hal kecil seperti ketidakhadiran dalam pertemuan dan 
lain-lain, yang tentunya bisa menghambat proses kegiatan kelompok.

b. Bagi BKKBN

1) Pihak penyelenggara program perlu meningkatkan dalam kegiatan pelatihan ketrampilan secara berkala, minimal diadakan pelatihan satu bulan sekali agar para anggota dapat mengembangkan usahanya masingmasing.

2) Pihak penyelenggara program perlu meningkatkan kegiatan evaluasi dan monitoring pada kelompok-kelompok UPPKS secara berkala sebagai bahan masukan untuk perkembangan program UPPKS kedepannya agar lebih baik lagi.

c. Bagi peneliti selanjutnya

Penulis mengharapkan semoga hasil penelitian ini dapat memberikan manfaat dan sumbangan pemikiran bagi para peneliti lain pada umumnya dan khususnya bagi peneliti sendiri.

\section{DAFTAR PUSTAKA}

Anwas, O.M. (2014). Pemberdayaan Masyarakat Di Era Global. Bandung: Alfabeta.

Anwar, K. Usaha Peningkatan Pendapatan Keluarga Sejahtera (UPPKS). BKKBN 2009. https://www.slideshare.net/ yakusa47/usaha-peningkatanpendapatan-keluarga-sejahterauppks. (diakses pada tanggal $18 \mathrm{Mei}$ 2018).

Anwar, K. Program Pemberdayaan Ekonomi Keluarga Peserta KB. BKKBN 2010. https://www.slideshare.net/yakusa47/p rogram-pemberdayaan ekonomikeluarga-peserta-kb. (diakses pada tanggal 18 Mei 2018).
Awang, A. (2010). Implementasi Pemberdayaan Pemerintah Desa: Studi Kajian Pemberdayaan Berdasarkan Kearifan Lokal di Kabupaten Lingga Provinsi Kepulauan Riau. Yogyakarta: PUSTAKAPELAJAR.

Buku Pegangan Pengurus Kelompok UPPKS: Pengelolaan Administrasi \& Keuangan Kelompok Seri 2. 2009. Provinsi Jawa Timur: BKKBN.

Buku Saku: Materi Bantu Penyuluhan Kependudukan, Keluarga Berencana dan Pembangunan Keluarga. 2015. Provinsi Jawa Timur: Perwakilan BKKBN.

Emzir. (2011). Metodologi Penelitian Kualitatif: Analisis Data. Jakarta: PT. RajaGrafindo Persada.

Mardikanto, T dan Poerwoko, S. (2015). Pemberdayaan Masyarakat Dalam Perspektif Kebijakan Publik. Bandung: Alfabeta.

Soetomo. (2015). Pemberdayaan Masyarakat: Mungkinkah Muncul Antitesisnya?. Yogyakarta: PUSTAKA PELAJAR.

Sugiyono. (2013). Metode Penelitian Kuantitatif, Kualitatif Dan R\&D. Bandung: Alfabeta.

Sugiyono. (2014). Memahami Penelitian Kualitatif. Bandung: Alfabeta

Suharto, E. (2014). Membangun Masyarakat Memberdayakan Masyarakat Kajian Strategis Pembangunan Kesejahteraan Sosial dan Pekerjaan Sosial. Bandung: PT. Refika Aditama.

Sukardi. (2004). Penelitian KualitatifNaturalistik Dalam Pendidikan. Yogyakarta: UNY. 